\title{
Mutual Responsibility For Mutual Service
}

BY JAMES E. BRYAN

$\mathrm{F}$ OUR OR FIVE years ago a peak daily attendance for our Newark Public Library main library might be between two thousand and twenty-five hundred persons. On the Monday after last Easter (1961) it was 3,983. On not one day of Easter week did attendance fall below two thousand, and our total for that week was 17,500 . This followed a Christmas period of high use which we studied by questionnaire method. The findings from about five thousand responses, which proved to be a 25 per cent sample, indicated why people came to our library, where they came from, and what they came for.

Slightly over 70 per cent came to the library for either school-connected, workconnected, or professional reading. Of those who came 64.1 per cent were students, of whom 30 per cent were highschool students and 70 per cent were college students. The high-school-level students represented 85 secondary schools in eight counties. The college students represented 175 colleges and universities in 30 states. Of those responding to the questionnaire, 50.8 per cent were not residents of Newark, but came from 187 different communities in New Jersey and 38 other towns and cities in 14 states. A good percentage of those in the sampling used both books and periodicals, or $\mathrm{mi}$ crofilms. During this study period the library circulated a few less than twentyfive thousand volumes during the twoweek period, of which 89 per cent was nonfiction and only Il per cent fiction. There were many times when there were not enough seats in the reference room to accommodate readers. It was necessary to open our meeting-room space to meet
Mr. Bryan is Director of the Newark Public Library and President of ALA.

the needs of our users and give them a place to sit down.

On a similarly busy day a year before, we had two thousand requests for individual back numbers of periodicals (which, incidentally, took eight full-time clerical assistants to handle). We were able to retain about six hundred from high-school students. These showed that 267 were for 66 separate titles for 19551960, 94 were for 44 separate titles for 1950-1954, 173 were for 63 separate titles for 1900-1949, and 14 were for 10 separate titles prior to 1900 . If anyone ever doubted the direct connection of the public library to the educational process, this use should set him straight.

Our library is not complaining about this work load, we are pleased that we could handle it. We know that many other libraries in the state were also deluged, but if a high-school student travels as much as sixty miles to find a library to meet his needs, and if this situation is duplicated many times, it serves to emphasize that there are not enough good libraries and book collections to meet the need.

It may come as a surprise that this increased pattern of use is taking place in the library of a community which has decreased in population from 438,000 to 405,000 in the last decade and in a county whose population increased only from 905,000 to 923,000 in the last ten years. Essex County is also one of the so-called "better library counties" in the United States. The school and public libraries 
are well above average, and our approximate $\$ 4.70$ per capita appropriation is exceeded by five other public libraries in Essex County.

The materials, collections, and services that high-school and college students are coming to us for are chiefly those which are not found in libraries of high schools, smaller colleges, or the smaller city libraries. This leads to the following conclusions: 1) There is a general inadequacy of library materials for high-school and for college and university students in the Northern New Jersey area; 2) There is poor distribution of the materials of learning that are available, both geographically in terms of political boundaries and in terms of the needs of individual institutions; 3) There is a lack of understanding among some of those responsible for the improvement of educational facilities as to whose problem this is; 4) There is a lack of communication among various institutions-public and private, academic and library-on this and related problems.

As an instance of lack of understanding and lack of communication, I would like to cite one case. There is an informal group of chief librarians of public libraries in Essex County which meets regularly. We have been discussing ways and means to improve library service. We are working well with public-school superintendents, high-school principals, and high-school librarians through a joint committee of these parallel groups to improve library service to high-school students. It has been our hope also to work out some form of communication so that a better understanding of the needs of college and university students might result. Our group, representing twentythree public libraries, invited the colleges and university librarians of eighteen colleges or university divisions in the area, with students in our respective communities or using our libraries extensively, to attend one of our meetings. Five or six came.
On the Friday after Thanksgiving of 1961, despite bad weather, we had a busy day at our main library. Attendance was 3,541 , and the number of periodical requests was about twelve hundred in our lending and reference department alone. From previous studies we could estimate that about sixteen to seventeen hundred persons were college and university students, and that eight hundred periodical requests were from college and university students.

I do not know how many college and university libraries in our area were open on that day, but we called twenty-five in our Northern New Jersey area and got either no answer or a report that the library was not open from twenty-two. Public libraries are closed on a number of holidays during the year, more perhaps than college and university libraries, but I have no reports that their borrowers overrun the college libraries at such times.

Our library does not object to serving students; we are happy and pleased to have them. They are fine young people with inquiring minds. In most cases they are well behaved, and many of them know what they want and where they are going. In general, they do not waste our time.

This is a good time to talk about mutual responsibilities. The Newark Public Library lends books for home use to those who live, work, attend school, or pay taxes in the city and to those who pay a nonresident fee of $\$ 5$. per year. We are open for reading-room or reference use to all persons who come to us. With our resident colleges we have an arrangement that nonresident students will first clear with their own college librarians to make sure that we are not serving a function that the college library can serve, but once a student has a borrower's card there is no review of his status for one year. Our constituency may be divided into two large but overlapping groups: 1) those who use our public library for reference 
and in-building services; 2) those who use our library to borrow for home reading purposes.

At the main library the first of these groups is increasing faster than the second, and more and more of our staff time, book, periodical, and microfilm money are going to meet their needs. For example, we are beginning to think in terms of duplicating the most-used periodicals indexed in the Readers Guide, duplicating the most-used encyclopedias, etc. Most of these users are the constituents of other libraries, too, school libraries, other public libraries, college and university libraries, and in some cases, special libraries of corporations.

The public library, historically, has opened its doors to everyone for in-building use, and now the metropolitan-area public libraries are being pressed to meet the work load placed on them. Even if most college and university libraries in our area were open in a holiday period we would probably have a busy time for several reasons: 1) because we have certain reference and periodical holdings that many college libraries do not have; 2) because for many persons our library is more convenient than the college library and library attendance can be combined with shopping and other city errands; 3 ) because the student is more likely to get more of what he needs in one place. (It is surprising how well students scout out the availability of library materials and know where they are most likely to get what they need in one form or another.); 4) because of limitations which some institutions place on their services, for example: a) Some college libraries will not borrow on interlibrary loan for undergraduates. They, therefore, go to the public library where they have borrowers' cards and which will borrow books from the other libraries for them. Our library, in rare but worthwhile instances, has even borrowed on interlibrary loan for high-school students; b) Some college libraries will not make photocopies for students, and most public libraries will do this.

There appears to be a tendency among some college and university libraries to give special services to certain groups, such as faculty, graduate students, honors students, etc., which are not extended to undergraduates. The undergraduate often goes to the public library, which gives all adult borrowers equal treatment.

The public library feels that it should be a responsive agency: responsive to educational, cultural and business trends. It should also be an anticipatory agency that looks ahead, foresees needs, and prepares to meet them. Educational needs and requirements are based largely on the programs of our institutions of formal education. These not only place a great burden on the library facilities of colleges and universities but on public libraries as well.

There have been times in our history when individuals, communities, states, or nations have undertaken extraordinary means to meet extraordinary problems: war, famine, flood, drought, snow, power failure are some of these. There also comes a time when our educational system, or parts thereof, reach an emergency status and something extraordinary needs to be done. Much is being done; but with more colleges, more students being admitted to college, an upgrading of curricula, etc., library facilities adequate to need tend to lag behind. This places a greater and greater burden on the collections of the larger public libraries. What is true for Newark is true for New York, Boston, Hartford, Detroit, Cincinnati, and Los Angeles. It has often been said that when school libraries meet standards, when public libraries meet standards, and when college and university libraries meet standards, this problem and this need will disappear.

The achievement of standards of quality and quantity will help some but will not fully answer the kind of basic problem which the metropolitan area public 
library faces. The educational demands on libraries are growing more rapidly than the standards are being met. The standards say little about how an area or a region can secure the greatest amount of library service for the money expended for library service, or about which type of library is to serve which function and how. The standards say relatively little about cooperation among libraries to see that the greatest number of persons get the greatest range of books and services for the money spent.

The greatest obligation of all libraries is the obligation to see the whole problem of library need for all types of libraries and for all types of users and to cooperate to see that several constructive steps take place. There must be a review of the regulations of each library to see how these might be liberalized to give greater service to one's immediate community or clientele; a willingness not to undertake new programs or new curricula without adequate preparation; a willingness to share in areas of subject specialization so that funds can be used to benefit the greatest area and the greatest number.

Where, for reasons of policy, an individual library must withdraw services which it has rendered to an outside constituency, it is essential that there be plenty of warning, because the repercussions are widespread. A college or university that thinks it is helping the local public library by terminating services to townspeople may be serving this end, but it is also placing greater demands on public and college libraries twenty-five to fifty miles away. The problem is not the termination of services but how and when the step is taken. This applies equally to public libraries which have taken steps to restrict use. The development of a grid of library resources in any given area, with a modus operandi, a method of referral from one library agency to another, is required.

Most needed of all is a sense of mutual helpfulness and cooperation, a willingness to talk over problems of which library is to supply what, who is to develop this special collection or that. There needs to be mutual helpfulness in budget improvement for all types of libraries. There is no reason why public librarians should not speak for college and university budget improvement and vice versa. We are still too afraid that some other institution will get more and we will get less. Mutual help can achieve more for all.

Public libraries in metropolitan areas need, and must have, a broader basis of support than the local real-property tax or parts of an across-the-board type of state aid. There must be some recognition of the value and the cost of the regional library center and its maintenance of reference and research collections.

Finally, there is the need to understand that this country at this time cannot afford to let one worthy student be denied appropriate educational materials. Our problems vis-á-vis the outside world are such that we cannot let one person fail to make the best use of his abilities. We must cooperate to see that needs are met. The least that we can do, if we cannot meet the needs in our own institutions, is jointly and cooperatively to work to find ways and means for satisfying them.

To date public libraries generally (and the Newark Public Library specifically) have not reduced services to any person or group beyond the normal constituency. In most respects collections and services are better than they were last year, but they are still not good enough in quality and quantity to meet the needs placed on them. We are actively encouraging forms of cooperation with all types of libraries to the end that the whole Northern New Jersey area gets the greatest library service possible for the tax money expended and that no individual with a need for educational materials is refused the opportunity to use them. 